\title{
Genotyping of MRSA by Coa and Spa Gene Polymorphism among Nasal Carriage of Health Care Workers and Patients Clinical Isolates at Ismailia General hospital Serry F. M., Kadry A. A. and. Mansour M. K. Microbiology and Immunology Department, Faculty of Pharmacy, Zagazig University
}

\begin{abstract}
Staphylococcus aureus is a frequent cause of infections in both the community and hospital. Methicillin-resistant Staphylococcus aureus is a common nosocomial pathogen that causes the infections in different department of the hospital. Present study was conducted in Ismailia General Hospital to screen the nasal carriage of Methicilin resistant Staphylococcus aureus among health care worker who have contact with patients to help in control the spread of this pathogen from the health care workers to the patients. A total of 400 samples: 230 nasal swabs from healthy medical staff and worker and 150 patients' clinical specimens and 20 environmental swabs were subjected to bacteriological investigation following standard protocol. Sixty two isolates belong to $S$. aureus from 400 isolates. Out of twenty eight isolates were Methicillin-resistant Staphylococcus aureus. Antimicrobial susceptibility test was performed by disk diffusion method as per the CLSI guidelines. MecA gene was identified for isolates at 310bp. Genotyping by PCR-RFLP of Coa and Spa gene was identified for MRSA isolates has a special role in assessing the relatedness of MRSA isolates and its control.
\end{abstract}

\section{Introdution}

$S$. aureus has been recognized as an epidemiologically important pathogen.S. aureus infections in hospitalized patients have severe consequences ranging from benign superficial skin infections to life threatening infections like Endocarditis, Pneumonia, Meningitis and Septicemia. ${ }^{(1)}$ Methicillin was introduced to treat S. aureus infections, but in 1961, $S$. aureus isolates that had acquired resistance to methicillin (methiciliin-resistant S.aureus) were reported. $^{(2)}$ Meticillin-resistant Staphylococcus aureus (MRSA) infections, are a long-lasting problem of health care associated infection. A widespread of strains and therapeutically difficult infections are associated with increased mortality and morbidity. The association between $S$ aureus nasal carriage and staphylococcal disease was first reported by 
Danbolt in1931, who studied furunculosis. ${ }^{(3)}$ Colonization of $S$. aureus at multiple body sites occurs; anterior nares are the most frequent carriage site. Nasal colonization can be an indicator of high risk for subsequent infection as MRSA is a well-known risk factor whenever $S$. aureus colonization is present. Health care workers are an important reservoir of $S$. aureus and several studies has observed the rate of nasal carriage amongst $\mathrm{HCWs}$ ranging from $16.8 \%$ to $56.1 \%$. $^{(4)}$ Colonised HCWs may develop infection or may remain asymptomatic, but they are a potential source to the patients and other HCWs. ${ }^{(5)}$ So identification of health care workers (in outbreak settings) colonized with MRSA, combined with hand hygiene and other precautions have been shown to be effective in reducing the transmission and controlling the spread of MRSA.

Typing techniques have been developed to discriminate between the related and unrelated MRSA strains. ${ }^{(6)}$ Traditionally, phenotypic methods including antibiotic susceptibility testing and bacteriophage typing were used to distinguish between MRSA isolates. (7)

Genotyping methods by PCR restriction fragment length polymorphism (RFLP) for two species-specific proteins, coagulase (coa) and protein A (spa), was support epidemiological typing. The coagulase protein is an important virulence factor of MRSA. Coa has a polymorphic repeat region that can be used for typing of MRSA isolates. ${ }^{(8)}$ Its discriminatory power depends on the variability of the region containing the $81 \mathrm{bp}$ tandem repeats at the $3^{\prime}$ coding region of the gene. It differs both in the number of tandem repeats and the restriction sites among different isolates. ${ }^{(9)}$ Protein A is a surface protein known to carry polymorphic regions. The spa gene harbors a number of functionally distinctive regions, called $\mathrm{X}$ region, ${ }^{(10)}$ which is polymorphism widely used as a base for genotyping methods, the discriminatory power of which allows the recognition of small differences among genetically related strains and enables effective epidemiological investigation. ${ }^{(1)}$ It includes a varying number of highly polymorphic $24-\mathrm{b}$ prepeats. The aim of this study was to evaluate PCRRFLP as a molecular typing technique for MRSA strains on the basis of protein A and coagulase gene polymorphisms and to verify their ability in assessing the relatedness of MRSA isolates between nasal carrier of healthy care worker and clinical specimens of patients.

\section{Material and methods}

1. Sample Collection and Bacterial Spe cies Identification

Atotal of 400 isolates : 150 patients clinical specimens were collected $\mathrm{fr}$ om different department in Ismaillia 
General Hospital and 230 nose swab specimens from the mentioned hospitals staff were collected during the period from first of January till the end of March 2011. Using microbiological standard met hods including, catalase, coagulase and manitol fermentation on manitt ol salt agar, the sixty two isolated $\mathrm{S}$. aureus was confirmed and tested for oxacillin resistance by oxacillin disk diffusion susceptibility methods according to CLSI 2012 . Out twenty eight isolates were considered MRSA as presented.

Susceptibility testing:

The antibiotic sensitivity of 28 MRSA isolates to the antimicrobial agents was carried out by the disk diffusion method according to CLSI2012 on Muller-Hinton agar were used Ampicillin (AMP,10 $\mu \mathrm{g})$, Amoxicillin-Clavulanic acid (AMC, 20/10 $\mu \mathrm{g}$ ), Vancomycin (VA, $30 \mu \mathrm{g})$, Gentamicin (GN, 10 $\mu \mathrm{g})$, Erythromycin (E, $15 \mu \mathrm{g})$, Cefotaxime (CTX, $30 \mu \mathrm{g}$ ), Clindamycin (DA, $2 \mu \mathrm{g})$, Sulfamethoxazole -Trimethoprim (SXT, 1.25/23.75 $\mu \mathrm{g}$ ), Imipenem (IPM, $10 \mu \mathrm{g}$ ), Rifampicin (RD, 5 $\mu \mathrm{g})$, Linezolid (LZ, $2 \mu \mathrm{g}$ ) and chloramphenicol (C, $30 \mu \mathrm{g})$ were obtained from Oxoid, Hamphsire England.

2- Multiplex PCR to detect mecA gene and IS432 ${ }^{(11)}$

Twenty eight MRSA isolates were tested for the presence of the 310 base pair (bp) PCR product of mecA gene, using the following primers:

Forward TGGCTATCGTGTCACAATCG $\left.3^{\prime}\right)$, reverse

CTGGAACTTGTTGAGCAGAG $3 ')$. And presence of the 444 base pair (bp) PCR product of IS432 gene as a positive control for the PCR, using the following primers: forward

$\left(5^{\prime}-\right.$ AGGATGTTATCACTGTAGCC $\left.3^{\prime}\right)$,

Reverse

$\left(5^{\prime}-\right.$

GATGTACAATGACAGTCAGG $\left.3^{\prime}\right)$. Ten micro liters of DNA samples was added to $90 \mu \mathrm{L}$ of PCR mixture each deoxynucleoside triphosphates, 100 pmol of each primer, and $1.25 \mathrm{U}$ of Taq DNA polymerase. After an initial denaturation step $\left(3 \mathrm{~min}\right.$ at $\left.92^{\circ} \mathrm{C}\right)$, 30 cycles of amplification were performed as follows: denaturation at $92^{\circ} \mathrm{C}$ for $1 \mathrm{~min}$, annealing at $56^{\circ} \mathrm{C}$ for $1 \mathrm{~min}$, and DNA extension at $72^{\circ} \mathrm{C}$ for 1 min with an increment of $2 \mathrm{~s}$ per cycle. The reaction was achieved with a final extension at $72^{\circ} \mathrm{C}$ for $3 \mathrm{~min}$. Amplification was carried out in a Gene $\mathrm{E}$ thermal cycler (Techne, Cambridge, United Kingdom).

2. Polymerase Chain Reaction for De tection of Coa and Spa Genes

(A)- PCR for Coa Gene Detection.

(9) Using the following primers:

Forward (5'-CGA GAC CAA GAT TCA ACA AG-3'), reverse (5'AAA GAA AAC CAC TCA CAT CA-3'). Which were designed to amplify the $3^{\prime}$ end hyper variable 
region containing $81 \mathrm{bp}$ tandem repeats of Coa gene. The amplification reaction consisted of :- Initial denaturation step at $94^{\circ} \mathrm{C}$ for $5 \mathrm{~min}$, followed by 30 cycles of denaturation at $95^{\circ} \mathrm{C}$ for $30 \mathrm{sec}$, annealing at $55^{\circ} \mathrm{C}$ for $45 \mathrm{sec}$, extension at $72^{\circ} \mathrm{C}$ for $2 \mathrm{~min}$, followed by final extension at $72^{\circ} \mathrm{C}$ for $7 \mathrm{~min}$.

-RFLP of Coa Gene PCR Products. ${ }^{(9)}$

Depending on the number of $81 \mathrm{bp}$ repeats, a strain analysis of PCR RFLP products was performed with HaeIII restriction enzyme (New England BioLabs, Frankfurt, Germany), where $10 \mu \mathrm{L}$ of PCR product of $\mathrm{Coa}$ gene was incubated with $6 \mathrm{U}$ of the enzyme at $37^{\circ} \mathrm{C}$ for $1 \mathrm{~h} 45 \mathrm{~min}$ in a water bath.

(B)- PCR for $S p a$ Gene Detection ${ }^{(12)}$ Using the following primers:

Forward (5'-ATC TGG TGG CGT AAC ACC TG-3'), Reverse (5'CGC TGC ACC TAA CGC TAA TG-3'). Which were designed to amplify the polymorphic $\mathrm{X}$ region that contains a variable number of $24 \mathrm{bp}$ tandem repeats of the Spa gene coding for protein A. Amplification reaction consisted of: Initial denaturation step at $94^{\circ} \mathrm{C}$ for 4 minutes, followed by 35 cycles of denaturation at $94^{\circ} \mathrm{C}$ for 1 minute, annealing at $56^{\circ} \mathrm{C}$ for 1 minute, extension at $72^{\circ} \mathrm{C}$ for 3 minutes, followed by final extension at $72^{\circ} \mathrm{C}$ for 5 minutes.

-RFLP of spa Gene PCR Products. ${ }^{(9,12)}$
Five $\mu \mathrm{L}$ of each Spa gene amplicon and 10 units of HaeII restriction enzyme (New England BioLabs, Frankfurt, Germany) were incubated at $37^{\circ} \mathrm{C}$ for 3 hours. The PCR products and restriction digest fragments were detected by electrophoresis in $2 \%$ agarose gel.

The interpretation criteria for identifying different strains were a single band difference. Unique PCR-RFLP patterns were assigned a genotype.

\section{Results:}

Identification of isolates

1 -The Results of identification of isolates from Patients

Among 150 patients clinical specimens from different hospital department were 26 positive $S$. aureus (17.3\% of total sample) isolates and out 13 isolates were considered MRSA $(50 \%$ of $S$. aureus). The higher percent of patients with positive MRSA in NICU department (100\%), then Orthopedic, ICU and burn unit $(50 \%)$, MRSA in surgery (44.4\%). There was high number of sample type with positive MRSA in blood samples $(66.6 \%)$, then urine $(50 \%)$, after that pus and sputum (40\%).

2. The Results of identification of isolates from Hospitals Staff

Among hospitals staff (doctors, nurses and servants) 230 specimens was collected, were 34 positive $S$. aureus isolates $(14.8 \%$ of total sample) and out 14 isolates were considered MRSA $(41.1 \%$ of $S$. aureus). The highest number of 
workers from total department with positive nasal carriage MRSA in the Anesthesia (25\%), Surgery (17\%), ICU $(13.3 \%)$ and Kitchen staff $(10 \%)$.

3. The Results of identification of isolates from Environmental swab From 20 environmental swabs was collected, only 2 isolates positive $S$. aureus (10\% of total sample) and out one isolate was considered MRSA ( $45 \%$ of

S. aureus).

Susceptibility testing

The twenty eight phenotypically identified for the MRSA isolates were tested for their susceptibility to 12 antimicrobial chemotherapeutic agents by disk diffusion method according to CLSI (2012) are shown in table (1)

All isolates were resistant to Ampicillin, Cefotaxime and AMC. However, all MRSA isolates were susceptible to Linezolide $(100 \%)$ and Rifampin $(100 \%)$ then Imipenem (92\%) followed by Vancomycin (89\%) and Clindamycin (82\%) SXT (61\%), Erythromycin and Gentamicin $(50 \%)$,

Chloramphenicol (46\%) .

Detection of mecA Gene for confirmation of MRSA

Multiplex PCR which used for amplification and detection of $m e c A$ genes of MRSA and IS431, $(92.8 \%)$ give band at $310 \mathrm{bp}$ of mecA gene from total 28 MRSA isolates. IS431 gene give band at $444 \mathrm{bp}$, shown in figure(1).
Genotyping of MRSA isolates

A-Coagulase Gene Typing

The isolates were primarily classified according to the number and size of coa amplicon and secondarily on the number and sizes of the restriction fragment.

PCR amplification of the coa gene yielded products of 7 sizes, ranging from 567 to1134 bp $(567,648,729$, 810, 891, 972, 1134). Electrophoresis analysis generated 2 different band types (coI, coII) and 6 types of pattern. The majority of MRSA strains showed single band: $(18 / 28=64 \%)$. The most common PCR coa gene product shown was the $810 \mathrm{bp}$ band size product (Table 2, Figure2).

- Coa-RFLP Typing Using HaeIII Restriction Enzyme

Restriction digestion was performed on the amplified coagulase PCR product with HaeIII . The bands produced were multiples of 81 , divided into 5 band classes of CoaI. Five distinct RFLP banding pattern (digested as a, b, c, d, e) and CoaII , 12 sub types designated as (CoaIa1, 2/CoaIb1, 2, 3, 4, 5/ CoaIc/ CoaId1, 2/CoaIe and CoaII) were obtained. The majority of strains $(11 / 28=39 \%)$ belonged to RFLP banding pattern CoII (Table 2, Figure2). DI value of Coa-RFLP typing was 0.81 .

B-Spa Gene Typing

The isolates were primarily classified according to the number and size of Spa amplicon and secondarily on the number and sizes of the restriction fragment. 
The size of the PCR product ranged from 210 to $1512 \mathrm{bp}(216,360,840$, $984,1272,1296,1320,1464$ and 1512). These PCR product generated 3 major type (SI- SIISIII) based on number of band and 11 subtypes based on molecular size (SI a ,b ,c ,d ,e/SII a ,b ,c ,d /SIII a ,b ) as shown in (Table3, Figure 3).

Spa-RFLP Typing Using HaeII Restriction Enzyme

Restriction digestion was performed on the amplified spaPCR product with HaeII .The bands observed to be multiples of 24. Thirteen distinct banding patterns as (SI a, b, c, d, e / SII a (a1, a2), b (b1, b2), c, d/ SIII a, b ). Most strains belonged to pattern SIIa $_{1}$ then pattern SIb (Table3, Figure 3). DI value of spa-RFLP typing was 0.86 .

Correlation between Antibiotype, Coa-RFLP typing and Spa-RFLP typing:

The studied isolates could be distinguished from each other based on 3 typing methods (antibiotyping, coa - RFLP pattern and spa-RFLP pattern).

Calculating the discrimination index for the 3 typing methods used in this study, revealed that it was 0.85 , 0.81 , and 0.86 for antibiotyping , coa- RFLP typing, and spa-RFLP typing respectively. Highest discriminatory index was provided by combination of all methods (0.86). Combination of all typing methods could differentiate MRSAisolates into 17 groups, the commonest group1: (5 isolates), of type (antibiotype 2- coa pattern CoII -spa pattern $\mathrm{SIb}$ ) followed by group 2 :( 4 isolates), of type (antibiotype 3-coa pattern CoII spa patternSIIa 1 ) and group 3 : ( 2 isolates), of type (antibiotype 6-coa pattern CoIb1 - spa pattern SId) . These groups considered as epidemic, (epidemiologically related i.e. association found in terms of time \& location). Seventeen isolates were classified as sporadic (epidemiologically unrelated i.e. no association found in terms of time \&

location).

Correlations between various typing methods are presented in tables (12 and1 3).

Studying the 5 isolated epidemiologically related strains from an outbreak in Surjury department (2 doctors staff and 3 patients (wound sample), they were found to be homogeneous using the 3typing methods, all isolates were of (antibiotype 1- coa pattern F spa pattern II).

The 4isolated epidemiologically related strains from ICU: 1 nasal swap of ICU doctor, 3 deffrint sample of patient: 1 sputum, 2 blood.

The 2 isolated epidemiologically related strains from NICU: 2 blood sample of patient from NICU. 
Table (1) Antibiotic susceptibility of MRSA isolates to different antimicrobial chemotherapeutic agents

\begin{tabular}{|c|c|c|c|c|c|c|}
\hline \multirow{3}{*}{ ANTIBIOTIC DISC } & \multicolumn{6}{|c|}{ Number and percentage of isolates } \\
\hline & \multicolumn{2}{|c|}{$\mathbf{R}$} & \multicolumn{2}{|c|}{$\mathbf{I}$} & \multicolumn{2}{|c|}{$\mathbf{S}$} \\
\hline & NO. & $\%$ & NO. & $\%$ & NO. & $\%$ \\
\hline Oxacillin (ox) & 28 & $100 \%$ & 0 & 0 & 0 & 0 \\
\hline Ampicillin (AMP) & 28 & $100 \%$ & 0 & 0 & 0 & 0 \\
\hline Gentamicin $(\mathrm{CN})$ & 8 & $28 \%$ & 8 & $28 \%$ & 14 & $50 \%$ \\
\hline Clindamycin (DA) & 4 & $15 \%$ & 1 & $3 \%$ & 23 & $82 \%$ \\
\hline Erythromycin (E) & 14 & $50 \%$ & - & - & 14 & $50 \%$ \\
\hline $\begin{array}{l}\text { Trimethoprim/ } \\
\text { Sulphamethoxazol } \\
\text { (SXT) }\end{array}$ & 7 & $25 \%$ & 4 & $14 \%$ & 17 & $61 \%$ \\
\hline $\begin{array}{l}\text { Amoxycillin/ } \\
\text { Clavulanate (AMC) }\end{array}$ & 24 & $86 \%$ & 4 & $14 \%$ & - & - \\
\hline Imipenem (IPM) & 2 & $7 \%$ & 0 & 0 & 26 & $92 \%$ \\
\hline Rifampicin (RD) & 0 & 0 & 0 & 0 & 28 & $100 \%$ \\
\hline Linezolide (LZ) & 0 & 0 & 0 & 0 & 28 & $100 \%$ \\
\hline Cefotaxime (CTX) & 20 & $75 \%$ & 8 & $28 \%$ & - & - \\
\hline Vancomycin (VA) & 0 & 0 & 3 & $11 \%$ & 25 & $89 \%$ \\
\hline Chloramphenicol (C) & 7 & $25 \%$ & 8 & $29 \%$ & 13 & $46 \%$ \\
\hline
\end{tabular}


Table (2): Typing of MRSA isolates based on PCR-RFLP of Coa gene

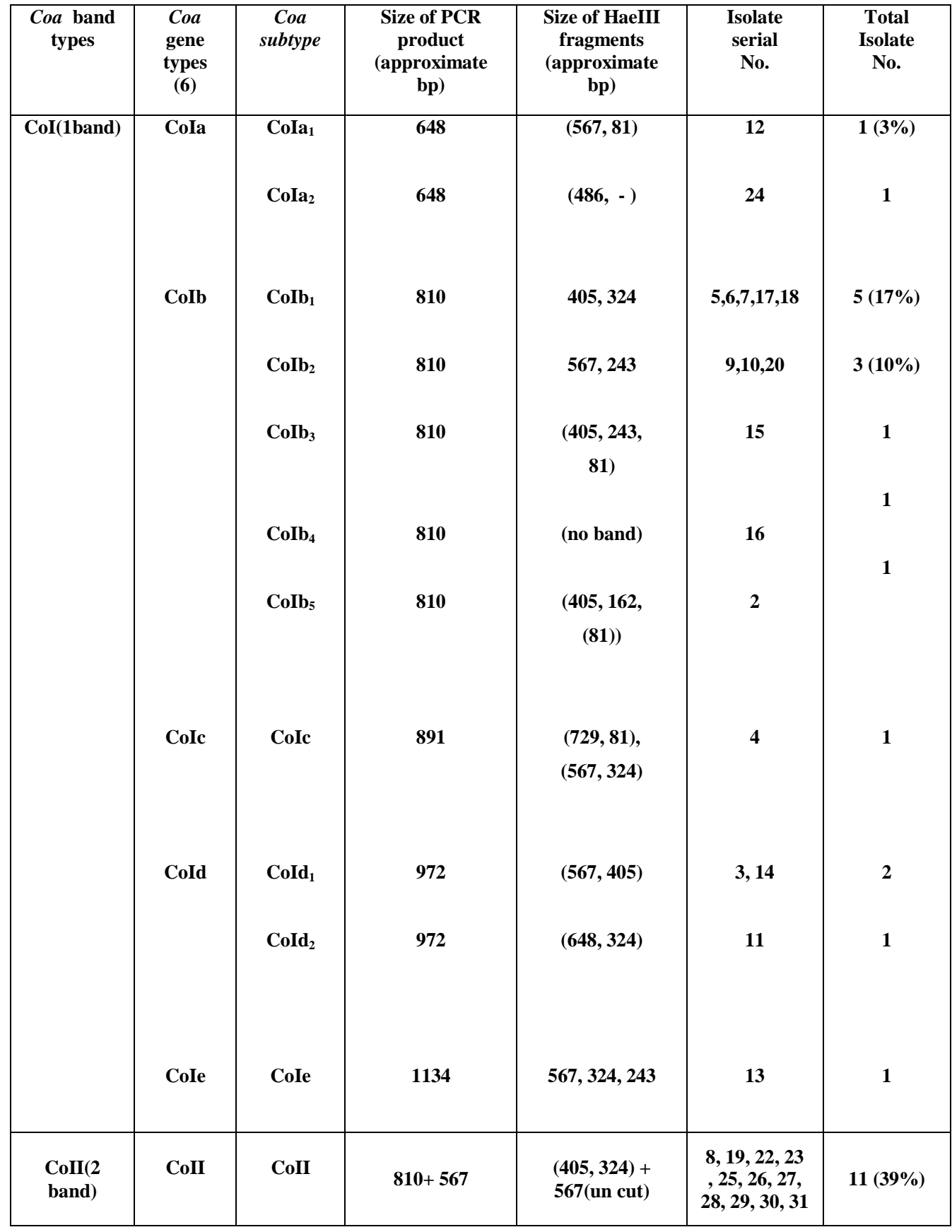


Table (3): Typing of isolates based on PCR-RFLP of spa gene

\begin{tabular}{|c|c|c|c|c|c|c|}
\hline $\begin{array}{l}\text { Spa } \\
\text { band } \\
\text { type (3) }\end{array}$ & $\begin{array}{l}\text { Spa } \\
\text { gene } \\
\text { (11) } \\
\text { types }\end{array}$ & $\begin{array}{l}\text { (13) } \\
\text { subtypes }\end{array}$ & $\begin{array}{l}\text { Size of PCR } \\
\text { Product } \\
\text { (approximat } \\
\text { bp) }\end{array}$ & $\begin{array}{l}\text { Size of HaeII } \\
\text { fragments } \\
\text { (approximate } \\
\text { bp) }\end{array}$ & $\begin{array}{l}\text { Total } \\
\text { isolate } \\
\text { no. }(\%)\end{array}$ & $\begin{array}{l}\text { Isolate } \\
\text { serial no. }\end{array}$ \\
\hline \multirow[t]{5}{*}{$\begin{array}{l}\text { S1 } \\
(1 \text { band })\end{array}$} & S1a & S1a & 984 & $\begin{array}{c}(960) \\
(696,288)\end{array}$ & 1 & 20 \\
\hline & S1b & S1b & 1296 & $\begin{array}{c}(1224) \\
(767,456)\end{array}$ & 5 & $\begin{array}{c}13,29,30, \\
27 \\
26,28\end{array}$ \\
\hline & S1c & S1c & 1320 & $\begin{array}{c}(1224) \\
(770,550)\end{array}$ & 1 & 22 \\
\hline & S1d & S1d & 1464 & $(\mathbf{8 8 8}, 456)$ & 2 & 17,18 \\
\hline & S1e & S1e & 1512 & $\begin{array}{c}\text { digestion) } \\
-\end{array}$ & 1 & 3 \\
\hline \multirow[t]{6}{*}{$\begin{array}{l}\text { SII } \\
(2 \\
\text { bands })\end{array}$} & SIIa & SIIa $_{1}$ & $\begin{array}{l}1296 \\
360\end{array}$ & $\begin{array}{c}1224 \\
744,456 \\
288\end{array}$ & 9 & $\begin{array}{c}2,5,9 \\
16,19,23 \\
25,31\end{array}$ \\
\hline & & $\mathrm{SIIa}_{2}$ & $\begin{array}{c}1296 \\
360\end{array}$ & $\begin{array}{c}768,456 \\
288 .\end{array}$ & 1 & 14 \\
\hline & SIIIb & SIII $_{1}$ & $\begin{array}{l}1296 \\
840\end{array}$ & $\begin{array}{l}744,528 \\
456,288\end{array}$ & 2 & 4,6 \\
\hline & & SIII $_{2}$ & $\begin{array}{c}1296 \\
840\end{array}$ & $\begin{array}{l}888,456 \\
528,288\end{array}$ & 3 & $7,8,15$ \\
\hline & SIIc & SIIc & $\begin{array}{c}1272 \\
216\end{array}$ & $\begin{array}{c}744,528 \\
210\end{array}$ & 1 & 12 \\
\hline & SIId & SIId & $\begin{array}{l}1320 \\
360\end{array}$ & $\begin{array}{c}1224 \\
888,456 \\
768,528 \\
288\end{array}$ & 1 & 24 \\
\hline \multirow[t]{2}{*}{$\begin{array}{l}\text { SIII } \\
(3 \\
\text { bands) }\end{array}$} & SIIIa & SIIIa & $\begin{array}{c}1080 \\
936 \\
360\end{array}$ & $\begin{array}{c}888,288 \\
936 \\
360\end{array}$ & 1 & 10 \\
\hline & SIIIb & SIIIb & $\begin{array}{l}1296 \\
984 \\
360\end{array}$ & $\begin{array}{c}840,456 \\
528,360 \\
288\end{array}$ & 1 & 11 \\
\hline
\end{tabular}




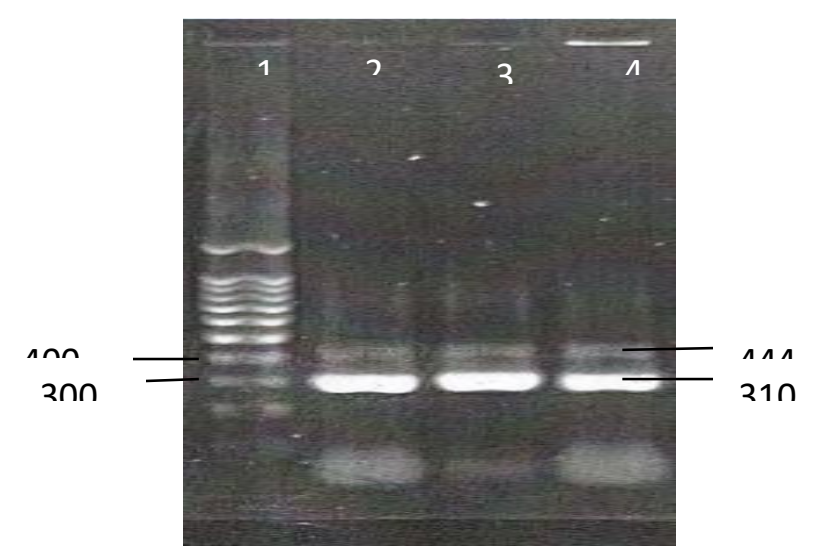

Figure 1:2\% agarose gel electrophoresis analysis of Multiplex- PCR amplification products of mecA gene of $310 \mathrm{bp}$ and IS431gene of $444 \mathrm{bp}$, extracted from $S$. aureus. Lane1: lanes 2,3: methicillin-resistant $S$. aureus (MRSA); lane 1: DNA molecular size marker (100 bp ladder).

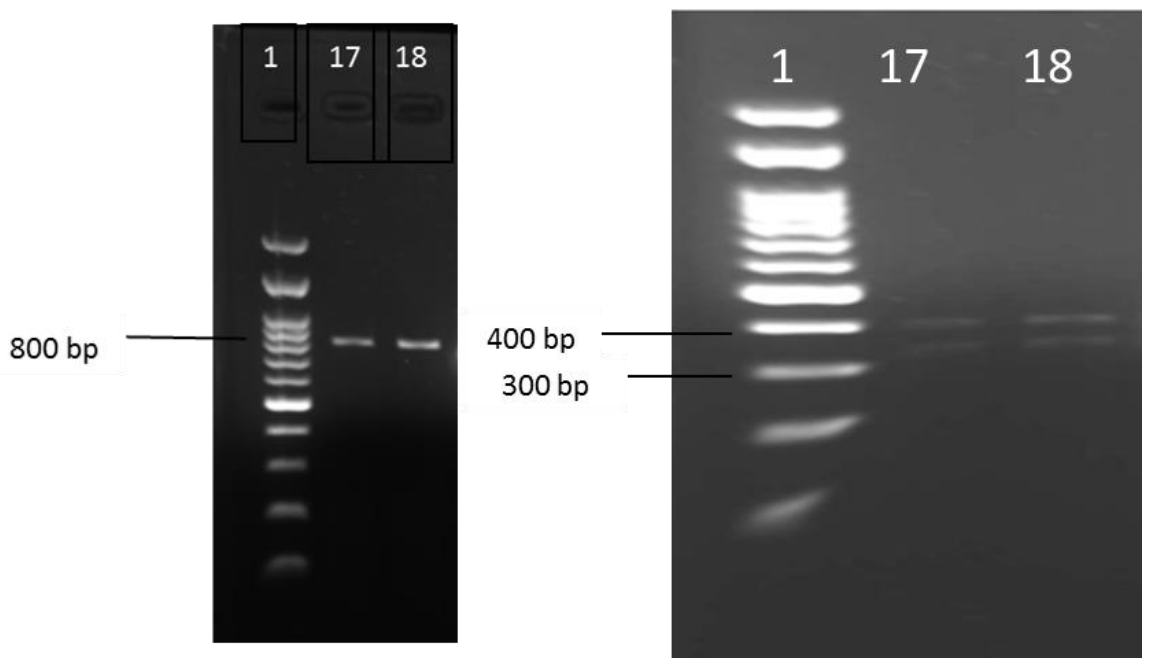

Figure 2: Representative 2\% agarose gel electrophoresis of $\mathrm{Coa}$ gene HaeIII restriction enzyme digestion PCR products, where lane 1 is DNA molecular size marker (100 bp ladder), (a) isolate 17, 18 showing single band $\mathrm{Coa}$ gene PCR products and (b) after cutting with HaeIII restriction enzyme, isolates 17, 18 give two bands of PCR-RFLP product. 

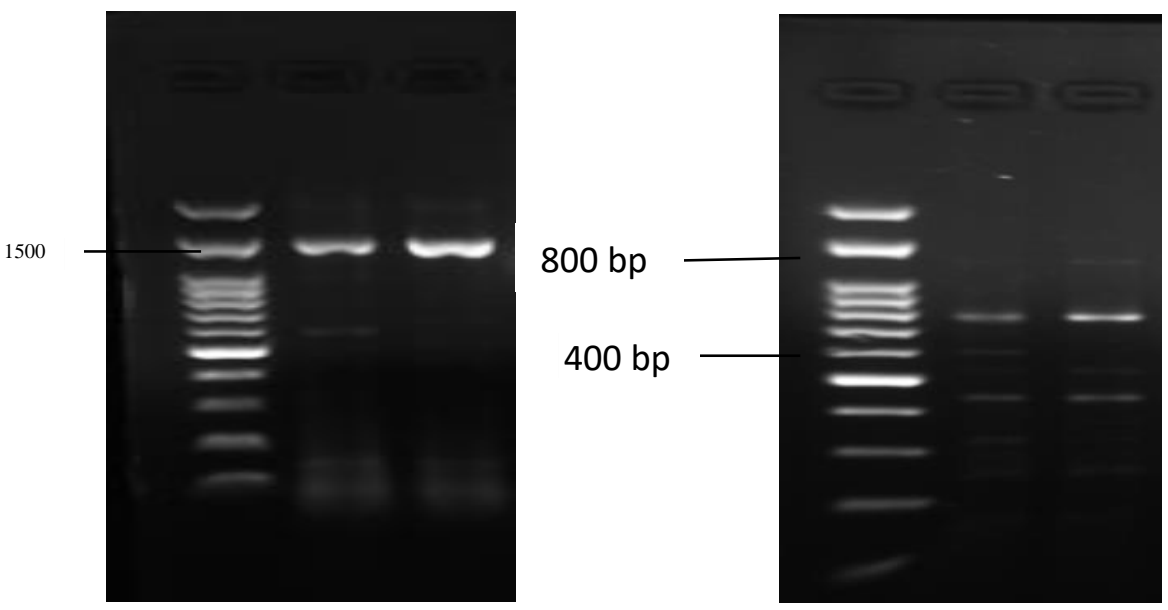

Figure 3: Representative 2\% agarose gel electrophoresis of Spa gene PCR products where lane1 is DNA molecular size marker (100 bp ladder). (a) Isolates 2 and 3 showing single band PCR products, (b) after HaeII restriction enzyme digestion PCR products and its corresponding 2 bands HaeII restriction digestion products.

\section{Discussion}

The prevalence of methicillin resistant $S$. aureus and inhibition of these infections and determination of spreading center in hospitals are definitely important subjects, the carriers of methicilln resistant strains have the original role in bacteria transmission. ${ }^{(13)}$ The current study showed methicillin resistance in $50 \%$ of S.aureus clinical isolates and $41.1 \%$ of $S$. aureus hospitals Staff's.

Various studies have shown different results of bacterial resistance and carriers which may be related to various bacterial detecting methods. Rashwan et al. $(2006)^{(14)}$ showed $55 \%$ methicillin resistant among $110 \mathrm{~S}$. aureus clinical isolates .

Mounir et al. (2013) ${ }^{(15)}$ showed $20 \%$ MRSA among $150 \quad S$. aureus clinical isolates.

Our study of MRSA nasal carrier not far away from Saroj et al. $(2013)^{(16)}$ study who showed 21 (53.8\%) MRSA among 39 S. aureus nasal carrier Staff.

Partha et al. (2015) ${ }^{(17)}$ study of 183 were nasal carriage of $S$. aureus in their anterior nares. Out of these, 39 $(21.47 \%)$ HCWs were detected as MRSA nasal carriers.

Kogekar et al. $(2015)^{(18)}$ showed $16(53.33 \%)$ nasal carriage of MRSA among $30 \mathrm{~S}$. aureus staff carriage at various hospital department. 
Genotyping by PCR-RFLP is a preliminary screening method for the epidemiological study of nosocomial infection caused by MRSA.

In the present study PCR-RFLP of Coa using HaeIII was conducted to 12 distinct RFLP banding pattern, this result not far away from Walker et al. (1998) ${ }^{(19)}$ showed the HaeIII digestion of the coa gene PCR products yielded 13 different RFLP patterns and also Lawrence et al. $(1998)^{(20)}$ study that showed after digestion with Haell, 17 RFLP patterns could be distinguished . Montesinos et al. (2002) ${ }^{(21)}$ study in four patterns of amplified Coa gene (co1to4) detected by using both AluI and HaeIII restriction enzymes.

Typing based on RFLP-PCR product of Spa gene using HaeII restriction enzyme was used in our study generated 13 distinct banding pattern. This result not far away from study of Omar et al. (2014) showed typing and HaeII Restriction digestion give12 subtypes designated

In Shakeri et al. (2010) ${ }^{(23)}$ study after digestion by HaeII, three patterns with 2, 3 and 4 fragments were observed.

The outcome of this study and the other similar researches, show that spa and coa typing are suitable methods for MRSA isolates typing because it is easy to use and interpret them, and that these methods can be useful in infection source detection and its control especially in epidemic situations.

\section{Reference}

(1)- Diekema et al (2001), Survey of infections due to Staphylococcus species: Frequency of occurrence and antimicrobial susceptibility of isolates collected in the United States, Canada, Latin America, Europe, and the Western Pacific region for the SENTRY Antimicrobial Surveillence Program, 1997-1999. Clinical Infectious Diseases; 32: 114-132.
(2)-Askarian
et
al
(2009),

Prevalence of nasal carriage of Methicillin-Resistant

Staphylococcus aureus and its antibiotic susceptibility pattern in healthcare workers at Nazmi Hospital, Shiran, Iran. International Journal of Infectious Diseases; 13: e241-e247.

(3)- Solberg et al (1965), A study of carriers of Staphylococcus aureus with special regard to quantitative bacterial estimations. Acta Med Scand Suppl; 436:

1-96.

(4)-Goyal et al (2002), Colonization of Methicillin Resistant Staphylococcus aureus among healthcare workers in a tertiary care hospital at Delhi.J Indian Journal of Medical Sciences; 56: 321-324.

(5)-Kirecci et al (2010), Aresearch of nasal Methicillin Resistant/ sensitive staphylococcus aureus and pharyngeal beta-hemolytic streptococcus carriage in Midwifery students in kahramanaras. J Turkey Ethiop Health Dev; 24: 57-60. 
(6)-Janwithayanuchit et al (2000), Idemiologic Study of MethicillinResistant Staphylococcus aureus by Coagulase Gene Polymorphism. Science Asia; 32: 127-132.

(7)-Shopsin et al (2001), Molecular epidemiology of Methicillin Resistant Staphylococcus aureus. EmergInfect Dis;7: 323-326.

(8)-Shopsin et al (2000), Use of coagulase gene (coa) repeatregion nucleotide sequences for typing of Methicillin-Resistant

Staphylococcus aureus strains. J Clin Microbiol; 38: 3453-3456.

(9)- Himabindu et al (2009), Molecular analysis of coagulase gene polymorphism in clinical isolates of Methicilin Resistant Staphylococcus aureus by restriction fragment length polymorphism Genotyping. Am J Inf Dis; 5: 170-176.

(10)-Frenay et al (1994), Discrimination of epidemic and non epidemic Methicillin Resistant Staphylococcus aureus strains on the basis of protein A gene polymorphism. J Clin. Microbiology; 32: 846-847.

(11)-Vannuffel et al (1995), Specific Detection of MethicillinResistant Staphylococcus Species.J Clinical Microbiology; 2864-2867

(12)-Wichelhaus et al (2001), Rapid molecular typing of Methicillin-

Resistant Staphylococcus aureus by PCR-RFLP, Infection Control and Hospital Epidemiology; 294-298. (13)-Schmitz et al (1998), Typing of

Methicillin-
Resistant Staphylococcus aureus isolates from Dusseldorf by six genotypic methods. J Medical Microbiology; 341-351.

(14)-Rashwan et al (2006), Screening of Nosocomial Methicillin-Resistant

Staphylococcus aureus (MRSA) in The Intensive Care Units of Assiut University Hospital. J Egyptian Journal of Medical Microbiology;79-88.

(15)-Mounir et al (2014), Phenotypic and Genotypic Characterization of Nosocomial Isolates of Staphylococcus aureus with Reference to Methicillin Resistance. Tropical Journal of Pharmaceuticalt; 1239-1246. (16)-Partha et al (2015), Nasal carriage of staphylococcus aureus and the quantum of their methicillin resistance amongst the health care workers in a peripheral tertiary care centre of Eastern India. J Journal of Evolution of Medical and Dental Sciences; 15537-15542.

(17)- Saroj et al (2013), A study of nasal carriage of MRSA among the health care workers of a tertiary care hospital, bangalore. J International Journal of Basic and Applied Medical Sciences; 3-7. (18)-Kogekar et al (2015), High level of MRSA colonization in health care worker: Alarm to implement health care policy. J World Journal of Clinical Pharmacology, Microbiology and Toxicology; 21-25.

(19)-Walker et al (1999), Subtyping of Methicillin- Resistant 
Staphylococcus aureus isolates from the North-West of England a comparison of standardized pulsedfield gel electrophoresis with bacteriophage typing including an inter-aboratory reproducibility study. J Med. Microbial; 297-301. (20)-Lawrence et al (1996), Use of the coagulase gene typing method for detection of carriers of Methicillin-

Staphylococcus

Resistant Antimicrobial Chemotherapy; 68796.

(21)-Montesinos et al (2002), Epidemiologic genotyping of Methicillin-

Resistant Staphylococcus aureus by pulsed-field gel electrophoresis at a
University Hospital and comparison with antibiotyping and protein $\mathrm{A}$ and coagulase gene polymorphisms. J Clinical Microbiology; 2119-2125. (22)- Omar et al (2014), Molecular Typing of Methicillin Resistant Staphylococcus aureus Clinical Isolates on the Basis of Protein A and Coagulase Gene Polymorphisms. J International Journal of Microbiology; 95-112 (23)-Shakeri et al (2010), Spa diversity among MRSA and MSSA strains of Staphylococcus aureus in north of Iran. J International Journal of Microbiology.; p.5

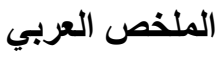

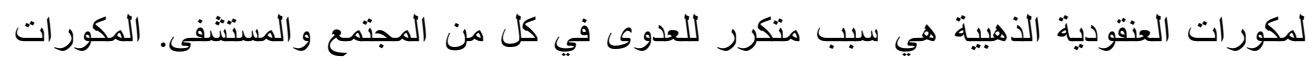

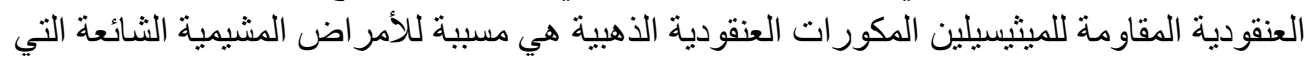

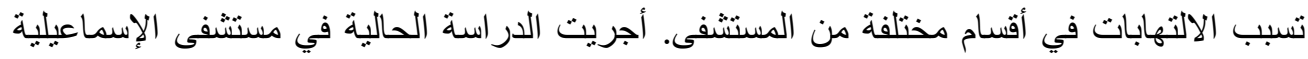

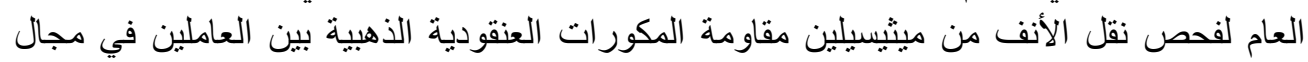

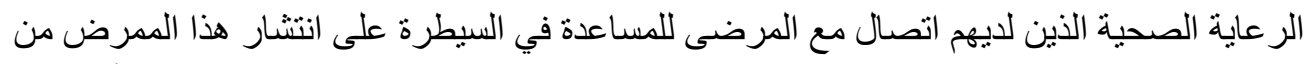

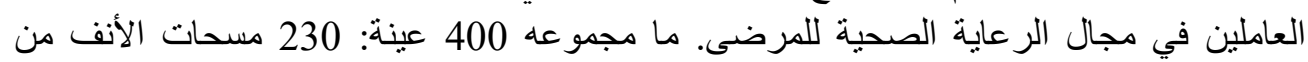

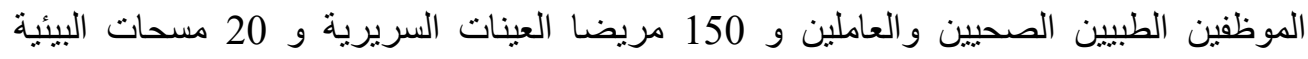

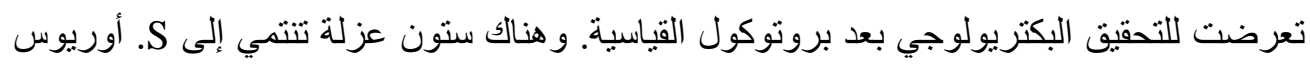

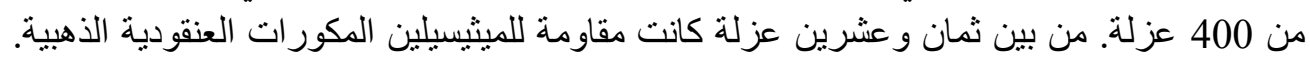

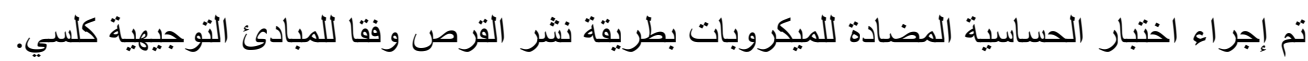

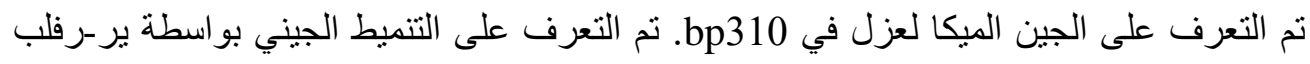
لجين كوا وسبا لعقاقير مرسا لها دور خاص في تقييم علاقة عزلات لات مرسا ومكافحتها. 